\title{
Contamination of Lead and Mercury in Coal Basin of India
}

\author{
Reetu Sharma1, Shobhana Ramteke1, Khageshwar Singh Patel1*, Sudhanshu Kumar², \\ Bighnaraj Sarangi ${ }^{2}$, Shankar Gopal Agrawal' ${ }^{2}$, Lesia Lata ${ }^{3}$, Huber Milosh ${ }^{3}$ \\ ${ }^{1}$ School of Studies in Chemistry/Environmental Science, Pt. Ravishankar Shukla University, Raipur, India \\ ${ }^{2}$ Analytical Chemistry Section, CSIR-National Physical Laboratory, New Delhi, India \\ ${ }^{3}$ Department of Soil Science/Geology, Maria Curie-Skłodowska University, Lublin, Poland \\ Email: "patelkhageshwarsingh@gmail.com
}

Received 10 November 2015; accepted 22 December 2015; published 25 December 2015

Copyright (C) 2015 by authors and Scientific Research Publishing Inc.

This work is licensed under the Creative Commons Attribution International License (CC BY).

http://creativecommons.org/licenses/by/4.0/

(c) (7) Open Access

\begin{abstract}
The coal is contaminated with toxic metals at the trace levels. They are released into the environment during mining, handling and burning of coal. The Korba basin has one of the largest coal exploitation areas in the country. In this work, contamination and sources of toxic metals i.e. Hg and $\mathrm{Pb}$ in the air, soil and sediment of the Korba basin, India are described. The concentration of Hg and $\mathrm{Pb}$ in the ambient air was ranged from $7.4-29$ and $7.0-585 \mathrm{ng} / \mathrm{m}^{3}$ with mean value of $18 \pm 4$ and $129 \pm 104 \mathrm{ng} / \mathrm{m}^{3}$ in the winter season. The mean concentration of $\mathrm{Hg}$ in the soil and sediment was $0.22 \pm 0.03$ and $0.44 \pm 0.08 \mathrm{mg} / \mathrm{kg}$, respectively. The higher concentration of $\mathrm{Pb}$ in the environmental samples was observed.
\end{abstract}

\section{Keywords}

Lead, Mercury, Aerosol, Soil, Sediment

\section{Introduction}

Heavy metals i.e. $\mathrm{Pb}$ and $\mathrm{Hg}$ are highly toxic to the developing brain and nervous system [1]-[2]. Coal is a naturally occurring combustible fuel containing the toxic metals at trace levels [3]-[5]. They are emitted from the thermal power plant stacks in both gaseous and particulate forms by retaining some fractions in the ash residues [6]-[8]. They are persistent in the environment, could enter bodies through the oral route and prove a great threat to people, especially those living in the vicinity of these thermal power plants. The contamination of environment with the $\mathrm{Pb}$ and $\mathrm{Hg}$ in various parts of the World was reported [9]-[45]. In the present work, contamination,

\footnotetext{
${ }^{*}$ Corresponding author.
}

How to cite this paper: Sharma, R., Ramteke, S., Patel, K.S., Kumar, S., Sarangi, B., Agrawal, S.G., Lata, L. and Milosh, H. (2015) Contamination of Lead and Mercury in Coal Basin of India. Journal of Environmental Protection, 6, $1430-1441$. 
enrichment and sources of $\mathrm{Pb}$ and $\mathrm{Hg}$ in the environment of the Korba basin, India are described.

\section{Methods and Materials}

\subsection{Study Area}

The Korba basin $\left(22^{\circ} 21^{\prime} \mathrm{N}, 82^{\circ} 40^{\prime} \mathrm{E}\right)$ has largest coal deposit in the country extending over $\approx 530 \mathrm{~km}^{2}$. Several open and underground coal mines are in operation with production of $>10,000 \mathrm{MT} / \mathrm{Yr}$ coal. They are consumed by the thermal power plants running in the basin for production of electricity $(40,000 \mathrm{MW})$ by pouring effluents into the environment. The population ( $\approx 0.5$ million) of the basin is exposed severely with particulate and fly ash pollution. The increased prevalence rate of air and water borne diseases in human and domestic animals was observed.

\subsection{Sample Collection and Meteorological Analysis}

The sampling network for collection of particulate matters (PM), soil and sediment is shown in Figure 1. The Lata Envirotech air sampler was used for the collection of the coarse particulate matters $\left(\mathrm{PM}_{10}\right)$. The $\mathrm{PM}_{10}$ was collected over the quartz filer paper (47-mm, Whatmann) at flow rate of $16 \mathrm{lit} / \mathrm{min}$. The sampler was run for duration of $24 \mathrm{hr}$ at the $1^{\text {st }}$ floor of the building ( $\geq 3 \mathrm{~m}$ above the ground level). Ten samples were collected from 10 different locations of the Korba basin during period: December, 2012-February, 2013.

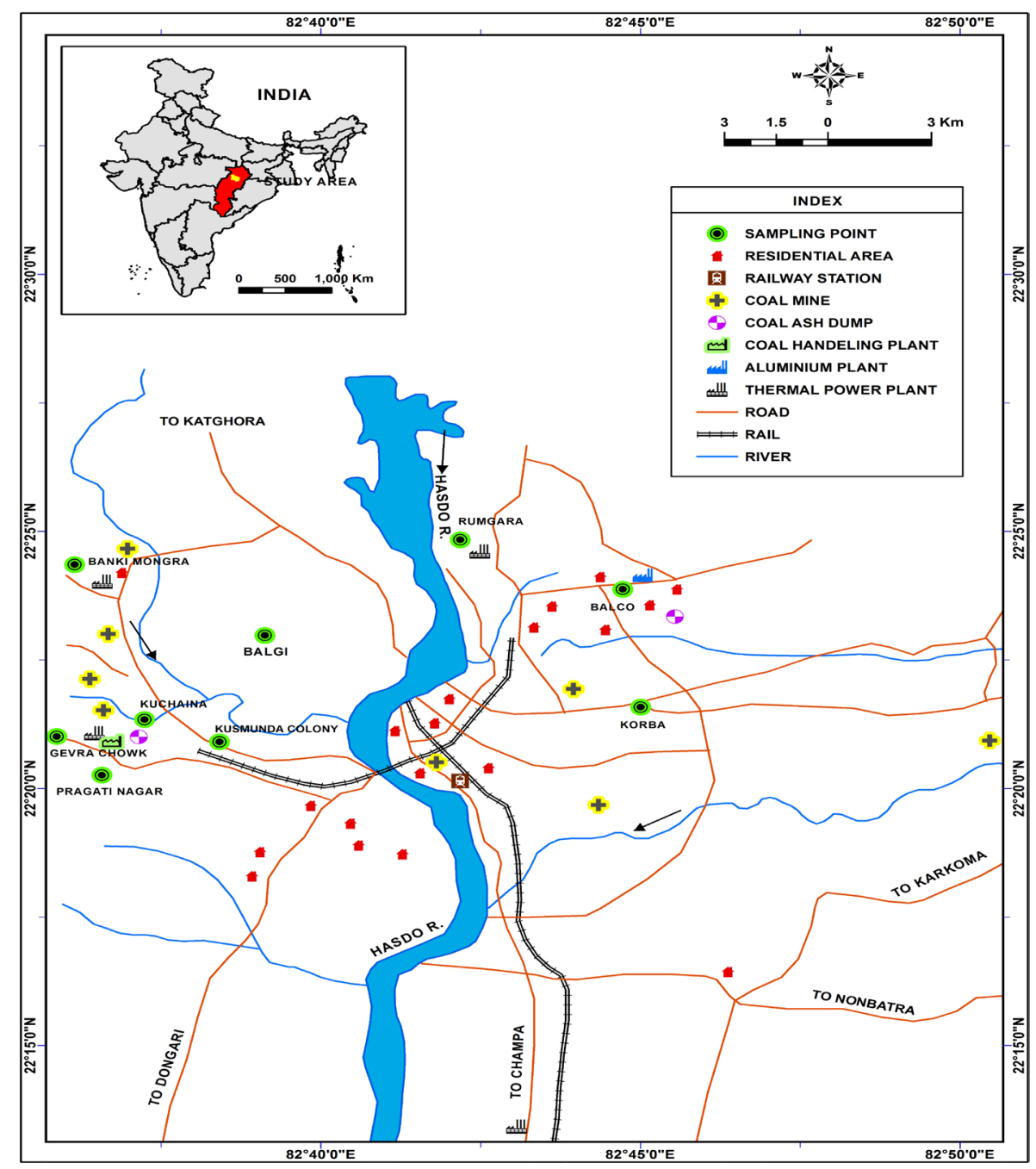

Figure 1. Representation of sampling locations. 
The Anderson sampler (1531-107B-G289X) with eight stages: $\mathrm{PM}_{10.0-9.0}, \mathrm{PM}_{9.0-5.8}, \mathrm{PM}_{5.8-4.7}, \mathrm{PM}_{4.7-3.3}, \mathrm{PM}_{3.3-2.1}$, $\mathrm{PM}_{2.1-1.1}, \mathrm{PM}_{1.1-0.7}$ and $\mathrm{PM}_{0.7}$ was used for the collection of respirable particulate matters in the segregation forms. The sampler was run for $72 \mathrm{hr}$ at four locations in January, 2013. The mass of dried loaded and blank filters were weighted out.

The surface soil $(0-10 \mathrm{~cm})$ samples from 30 locations of the basin were collected in January, 2013 [46]. The pond sediment was sampled from 26 locations of the basin in January, 2013 [47]. They were dried, crushed and sieved out particles of $\leq 0.1 \mathrm{~mm}$ sizes. The meteorological parameters i.e. ambient temperature (T), humidity (H), wind speed (WS) and wind direction (WD) were measured during the sampling period.

\subsection{Analysis}

The weighed amount of the sample was digested with acids by the microwave probe by using prescribed procedure. The $\mathrm{Pb}$ and $\mathrm{Hg}$ contents were analyzed by the Varian GF-AAS and CV-AAS techniques. The elemental or black carbon (BC or EC) and organic carbon (OC) were analyzed by the thermal and titration methods [48]. The $\mathrm{pH}$ value of soil and sediment extracts was determined, by shaking the soil or sediment sample in a 1:2 volume ratio with the deionized water.

\section{Results and Discussion}

The atmosphere of Korba basin is dusty due to huge emission of coal and ash particulates. The meteorology of the studied area during the winter period (2012-13) is summarized in Table 1. The value of T, H and WS was ranged from $8^{\circ} \mathrm{C}-30^{\circ} \mathrm{C}, 24 \%-93 \%$ and $3-8 \mathrm{k} / \mathrm{hr}$, respectively during the studied period. The air mass flow was varied from $\mathrm{E}$ to $\mathrm{S}$ with domination in the $\mathrm{SE}$ direction.

\subsection{Distribution of PM in Ambient Air}

The distribution of the PM in the ambient air is summarized in Table 2. Extremely high concentration of $\mathrm{PM}_{10}$ in ambient air during the winter period was observed, ranging from $196-775 \mu \mathrm{g} / \mathrm{m}^{3}$ with mean value of $390 \pm$ $137 \mu \mathrm{g} / \mathrm{m}^{3}$. The highest concentration of the $\mathrm{PM}_{10}$ was observed at location No. 2 due to input of the thermal power plant (TPP) effluents. The segregation chromatogram of the $\mathrm{PM}_{10}$ at four locations is summarized in Figure 2. The mean $(\mathrm{n}=4)$ relative concentration of $\mathrm{PM}_{10.0-9.0}, \mathrm{PM}_{9.0-5.8}, \mathrm{PM}_{5.8-4.7}, \mathrm{PM}_{4.7-3.3}, \mathrm{PM}_{3.3-2.1}, \mathrm{PM}_{2.1-1.1}$, $\mathrm{PM}_{1.1-0.7}$ and $\mathrm{PM}_{0.7}$ in the air was 17, 14, 9, 9, 15, 19, 12 and 6\%, respectively. At least, $52 \% \pm 14 \% \mathrm{PM}$ lie in the fine and ultrafine modes $(\leq 3.3 \mu \mathrm{m})$. The concentration of respirable PM in the air was found to be too much higher than recommended limit of $50 \mu \mathrm{g} / \mathrm{m}^{3}$ [49].

Table 1. Meteorology of the studied area.

\begin{tabular}{|c|c|c|c|c|c|c|c|c|}
\hline \multirow{2}{*}{ S. No. } & \multirow{2}{*}{ Sampling location } & \multirow{2}{*}{ Sampling date } & \multicolumn{2}{|c|}{ Temperature $(\mathrm{T}){ }^{\circ} \mathrm{C}$} & \multicolumn{2}{|c|}{ Humidity (H), \% } & \multirow{2}{*}{ WS km/hr } & \multirow{2}{*}{ WD } \\
\hline & & & Min & Max & Min & $\operatorname{Max}$ & & \\
\hline 1 & Korba city & $26-12-2012$ & 8 & 25 & 32 & 61 & 4 & E \\
\hline 2 & ITI colony & 27-12-2012 & 11 & 27.5 & 54.5 & 77 & 4.5 & SE \\
\hline 3 & CSEB colony & 01-01-2013 & 17.5 & 27.5 & 65 & 92 & 4.5 & E \\
\hline 4 & Manikpur & 02-01-2013 & 10.5 & 24 & 27 & 47 & 8 & SE \\
\hline 5 & BALCO & 05-01-2013 & 8.5 & 23.5 & 35 & 69 & 3 & SW \\
\hline 6 & Kusmunda & 06-01-2013 & 14.5 & 29.5 & 40 & 65 & 3.5 & NW \\
\hline 7 & Niharika & 08-01-2013 & 14 & 26.5 & 33 & 55.5 & 4 & $\mathrm{SE}$ \\
\hline 8 & Darri & 09-01-2013 & 15 & 27 & 28 & 47.5 & 4 & SE \\
\hline 9 & Mudapar & 13-01-2013 & 8 & 26 & 24 & 49 & 4 & SE \\
\hline 10 & Banki & $14-01-2013$ & 30 & 30 & 35 & 57 & 4 & SE \\
\hline
\end{tabular}

$\mathrm{E}=$ East, $\mathrm{S}=$ South, $\mathrm{W}=$ West, $\mathrm{N}=$ North. 


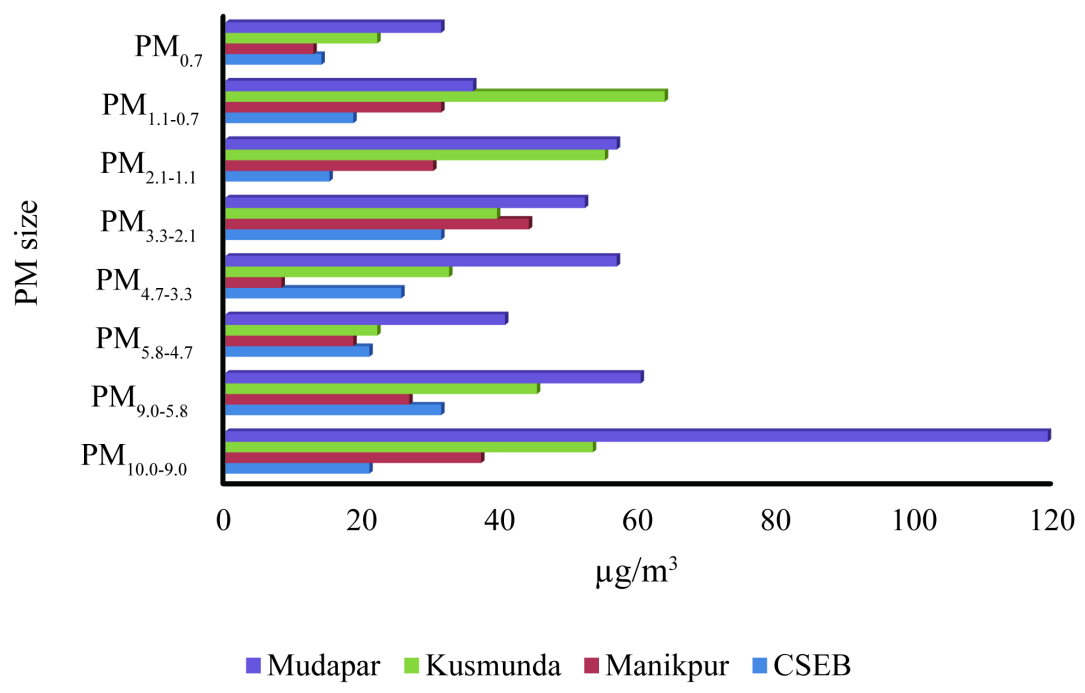

Figure 2. Segregation of $\mathrm{PM}_{10}$ in ambient air of Korba.

Table 2. Concentration of EC, $\mathrm{Pb}$ and $\mathrm{Hg}$ in ambient air and PM.

\begin{tabular}{|c|c|c|c|c|c|c|c|}
\hline \multirow{2}{*}{ S. No. } & \multirow{2}{*}{$\mathrm{PM}_{10}, \mu \mathrm{g} / \mathrm{m}^{3}$} & \multicolumn{2}{|c|}{ EC concentration } & \multicolumn{2}{|c|}{$\mathrm{Pb}$ concentration } & \multicolumn{2}{|c|}{ Hg concentration } \\
\hline & & Ambient air, $\mu \mathrm{g} / \mathrm{m}^{3}$ & $\mathrm{PM}, \%$ & Ambient air, ng/m³ & $\mathrm{PM}, \mathrm{mg} / \mathrm{kg}$ & Ambient air, ng/m ${ }^{3}$ & $\mathrm{PM}, \mathrm{mg} / \mathrm{kg}$ \\
\hline 1 & 315 & 26 & 8.2 & 101 & 320 & 18.8 & 59.7 \\
\hline 2 & 775 & 68 & 8.8 & 585 & 755 & 18.0 & 23.3 \\
\hline 3 & 196 & 16 & 8.2 & 109 & 556 & 7.4 & 37.7 \\
\hline 4 & 226 & 18 & 7.9 & 83 & 368 & 17.2 & 76.2 \\
\hline 5 & 209 & 16 & 7.5 & 59 & 280 & 15.0 & 71.8 \\
\hline 6 & 319 & 19 & 6.1 & 7.0 & 22 & 17.0 & 53.3 \\
\hline 7 & 283 & 22 & 7.7 & 71 & 252 & 24.3 & 86.1 \\
\hline 8 & 666 & 46 & 6.9 & 21 & 31 & 17.4 & 26.1 \\
\hline 9 & 666 & 53 & 8.0 & 193 & 290 & 29.0 & 43.5 \\
\hline 10 & 251 & 18 & 7.2 & 60 & 240 & 11.7 & 46.7 \\
\hline
\end{tabular}

\subsection{Distribution of Hg in Air, Soil and Sediment}

Mercury is a highly mobile metal, being liquid at room temperature, and behaves like organic compounds. The concentration of the $\mathrm{Hg}(\mathrm{n}=10)$ in the air (associated to $\left.\mathrm{PM}_{10}\right)$ was ranged from $7.4-29 \mathrm{ng} / \mathrm{m}^{3}$ with mean value of $18 \pm 4 \mathrm{ng} / \mathrm{m}^{3}$, Table 2. Its concentration in the $\mathrm{PM}_{10}(\mathrm{n}=10)$ was ranged from $23-86 \mathrm{mg} / \mathrm{kg}$ with mean value of $52 \pm 13 \mathrm{mg} / \mathrm{kg}$, Table 2. The higher concentration of Hg was observed in the studied area as compared to other regions of the World (i.e. Canada, China, Korea, Mexico, Taiwan, Thailand and Vietnam), may be due to huge coal burnings [11]-[15].

All the soil and sediment were composed of micrometer-scale grains with nano-scale structure. They were colored, ranging from whitish (W) to black (B) due to deposition of the fly ash and black carbon, Table 3 and Table 4. The mean $\mathrm{pH}$ value of the soil and sediment extracts were found to be slightly acidic, $\approx 6.6$ due to presence of high content of chloride and sulfate ions. The concentration of $\mathrm{Hg}$ in the soils $(\mathrm{n}=30)$ was ranged from $0.11-0.39 \mathrm{mg} / \mathrm{kg}$ with the mean value of $0.22 \pm 0.03 \mathrm{mg} / \mathrm{kg}$. The concentration of $\mathrm{Hg}$ in the soil of studied area was found to be comparable to the contents reported in other regions of the World (i.e. China, Greece, Iran, Poland, USA) [16]-[20]. 
At least 2-folds higher concentration of $\mathrm{Hg}$ in the sediment was observed and may be due to its highly mobile nature. The concentration of $\mathrm{Hg}$ in the sediments $(\mathrm{n}=26)$ was ranged from $0.12-0.82 \mathrm{mg} / \mathrm{kg}$ with the mean value of $0.44 \pm 0.08 \mathrm{mg} / \mathrm{kg}$. Extremely high concentration of $\mathrm{Hg}$ in the sediment of Hong Kong and Mumbai, maximum up to in the $0.855-2.66 \mathrm{mg} / \mathrm{kg}$ was reported [21]-[22]. The Hg loading in the sediments of Amazonian basin, Brazil, China, and Poland was ranged from 55 - $386 \mu \mathrm{g} / \mathrm{kg}$ [23]-[28].

Table 3. Distribution of $\mathrm{Pb}$ and $\mathrm{Hg}$ in soil.

\begin{tabular}{|c|c|c|c|c|c|c|}
\hline S. No. & Location & $\mathrm{pH}$ & Color & EC, \% & $\mathrm{Pb}, \mathrm{mg} / \mathrm{kg}$ & $\mathrm{Hg}, \mathrm{mg} / \mathrm{kg}$ \\
\hline 1 & Niharica & 7.0 & $\mathrm{~W}$ & 6.8 & 163 & 0.21 \\
\hline 2 & Kuan Bhatta & 7.0 & $\mathrm{~W}$ & 4.7 & 119 & 0.18 \\
\hline 3 & Railway Station & 7.0 & B & 3.5 & 95 & 0.11 \\
\hline 4 & Sitamani & 6.9 & BW & 6.8 & 126 & 0.23 \\
\hline 5 & Rajgamar & 6.9 & BW & 7.9 & 189 & 0.39 \\
\hline 6 & Rumgara & 6.9 & $\mathrm{~W}$ & 5.6 & 126 & 0.24 \\
\hline 7 & Darri dam & 6.4 & BW & 4.4 & 116 & 0.19 \\
\hline 8 & Chaildren Garden & 6.9 & BW & 4.5 & 116 & 0.20 \\
\hline 9 & Dipka Area & 6.5 & W & 4.5 & 117 & 0.14 \\
\hline 10 & Pragati Nagar & 6.9 & BW & 5.4 & 137 & 0.23 \\
\hline 11 & Gevera Chowk & 6.7 & W & 4.5 & 114 & 0.22 \\
\hline 12 & Kusmunda-I & 6.8 & B & 4.4 & 127 & 0.21 \\
\hline 13 & Kusmunda-II & 6.7 & $\mathrm{~W}$ & 5.7 & 126 & 0.25 \\
\hline 14 & Kusmunada-III & 6.7 & B & 6.3 & 154 & 0.25 \\
\hline 15 & Korba & 5.4 & BW & 7.3 & 190 & 0.37 \\
\hline 16 & Banki mongra & 6.5 & BW & 5.6 & 110 & 0.26 \\
\hline 17 & Balgi & 7.0 & $\mathrm{~W}$ & 5.5 & 88 & 0.25 \\
\hline 18 & Kuchaina & 6.8 & $\mathrm{~W}$ & 4.8 & 72 & 0.13 \\
\hline 19 & Balco & 5.7 & BW & 6.8 & 168 & 0.22 \\
\hline 20 & Bhadrapara & 7.0 & B & 5.7 & 106 & 0.11 \\
\hline 21 & Risdi Chowk & 6.7 & BW & 5.5 & 102 & 0.13 \\
\hline 22 & Manikpur & 6.6 & BW & 4.7 & 96 & 0.15 \\
\hline 23 & Dadar & 6.9 & BW & 5.7 & 138 & 0.24 \\
\hline 24 & SECL-I & 6.4 & $\mathrm{~W}$ & 5.7 & 140 & 0.21 \\
\hline 25 & Mudapar & 6.4 & $\mathrm{~W}$ & 5.5 & 119 & 0.24 \\
\hline 26 & Rampur & 5.8 & BW & 5.5 & 125 & 0.22 \\
\hline 27 & SECL-II & 6.2 & BW & 6.4 & 160 & 0.31 \\
\hline 28 & Belakachar & 6.1 & BW & 5.9 & 149 & 0.30 \\
\hline 29 & Urga & 7.1 & B & 5.5 & 129 & 0.26 \\
\hline 30 & Patadi & 7.5 & B & 7.9 & 194 & 0.38 \\
\hline
\end{tabular}

$\mathrm{B}=$ Black, $\mathrm{W}=$ White, $\mathrm{BW}=$ Blackish white. 
Table 4. Distribution of $\mathrm{Pb}$ and $\mathrm{Hg}$ in sediment.

\begin{tabular}{|c|c|c|c|c|c|c|}
\hline S. No. & Location & $\mathrm{pH}$ & Color & EC, \% & $\mathrm{Pb}, \mathrm{mg} / \mathrm{kg}$ & $\mathrm{Hg}, \mathrm{mg} / \mathrm{kg}$ \\
\hline 1 & Shakti Nagar & 5.6 & B & 8.5 & 33 & 0.16 \\
\hline 2 & Gevra, Dipka & 6.7 & B & 9.6 & 37 & 0.17 \\
\hline 3 & PN, Dipka & 6.8 & B & 8.8 & 49 & 0.23 \\
\hline 4 & Banki, Dipka & 7.4 & B & 4.8 & 47 & 0.25 \\
\hline 5 & Delwadih & 6.1 & B & 8.8 & 81 & 0.31 \\
\hline 6 & Shingali & 6.2 & B & 8.7 & 78 & 0.28 \\
\hline 7 & Kusmunda & 6.9 & B & 8.8 & 92 & 0.36 \\
\hline 8 & Rajgamar-3 & 6.7 & B & 8.6 & 74 & 0.26 \\
\hline 9 & Mudapar & 7.3 & B & 10.2 & 35 & 0.21 \\
\hline 10 & PN, Darri & 5.5 & BW & 11.1 & 106 & 0.61 \\
\hline 11 & Darri west & 6.1 & BW & 10.5 & 127 & 0.77 \\
\hline 12 & Jamnipali & 6.4 & W & 12.7 & 82 & 0.63 \\
\hline 13 & Gopalpur & 7.3 & $\mathrm{~W}$ & 13.8 & 120 & 0.82 \\
\hline 14 & HTPP, Darri & 6.1 & $\mathrm{~W}$ & 11.4 & 112 & 0.74 \\
\hline 15 & Manuikpur-1 & 6.6 & $\mathrm{~W}$ & 12.9 & 107 & 0.63 \\
\hline 16 & Manikpur-2 & 5.7 & $\mathrm{~W}$ & 3.7 & 31 & 0.30 \\
\hline 17 & Dader-1 & 8.1 & $\mathrm{~W}$ & 5.3 & 54 & 0.54 \\
\hline 18 & Dader-2 & 6.3 & W & 9.1 & 87 & 0.65 \\
\hline 19 & Kudarikhar & 5.8 & BW & 6.9 & 37 & 0.33 \\
\hline 20 & Naktikhar & 6.8 & BW & 10.1 & 75 & 0.53 \\
\hline 21 & Danras-1 & 5.4 & BW & 9.8 & 53 & 0.46 \\
\hline 22 & Danras-2 & 7.4 & BI & 3.6 & 26 & 0.12 \\
\hline 23 & SN-Balco & 8.1 & BW & 9.9 & 48 & 0.32 \\
\hline 24 & Pathadi & 6.2 & BW & 11.5 & 125 & 0.71 \\
\hline 25 & Dhendheni & 7.5 & B & 9.2 & 108 & 0.61 \\
\hline 26 & Sukhri & 7.6 & BW & 8.5 & 35 & 0.31 \\
\hline
\end{tabular}

$\mathrm{B}=$ Black, $\mathrm{W}=$ White, $\mathrm{BW}=$ Blackish white.

\subsection{Distribution of $\mathrm{Pb}$ in Air, Soil and Sediment}

Lead is least mobile and lethargic metal, generally deposited in surface soil. The concentration of $\mathrm{Pb}(\mathrm{n}=10)$ in the ambient air and $\mathrm{PM}_{10}$ was ranged from $7-585 \mathrm{ng} / \mathrm{m}^{3}$ and $22-755 \mathrm{mg} / \mathrm{kg}$ with mean value of $129 \pm 104$ $\mathrm{ng} / \mathrm{m}^{3}$ and $311 \pm 136 \mathrm{mg} / \mathrm{kg}$, respectively. Unlikely to $\mathrm{Hg}$, lead concentration in the soil was found to be remarkably higher than the sediment, may be due to its hydrophobic nature. Lead concentration in the soil and sediment of the studied area was ranged from $72-194$ and $26-127 \mathrm{mg} / \mathrm{kg}$ with mean value of $130 \pm 10$ and $75 \pm$ $13 \mathrm{mg} / \mathrm{kg}$, respectively. The concentration of $\mathrm{Pb}$ reported in the ambient air of various parts of the World i.e. China, India, Nigeria and USA was ranged from 3.9 - $1123 \mathrm{ng} / \mathrm{m}^{3}$ [29]-[33]. The Pb levels in soil and sediment of other regions of the World reported were ranged maximum up to $926 \mathrm{mg} / \mathrm{kg}$ [34] [45]. 


\subsection{Spatial and Vertical Distribution of Metals}

Similar spatial distribution patterns of $\mathrm{Hg}$ and $\mathrm{Pb}$ in the soil and sediment of the studied area was observed. The higher concentration of the metals was observed in the locations near point sources i.e. mining and thermal power plant, Figure 3 and Figure 4. The concentration of the Hg was found to increase as the depth profile was increased from $0-30 \mathrm{~cm}$, may be due to its hydrophilic nature and less binding with the soil organic compounds, Figure 5. However, the reverse trend was observed with $\mathrm{Pb}$, may be due to its hydrophobic nature and higher binding with the soil components, Figure 5.

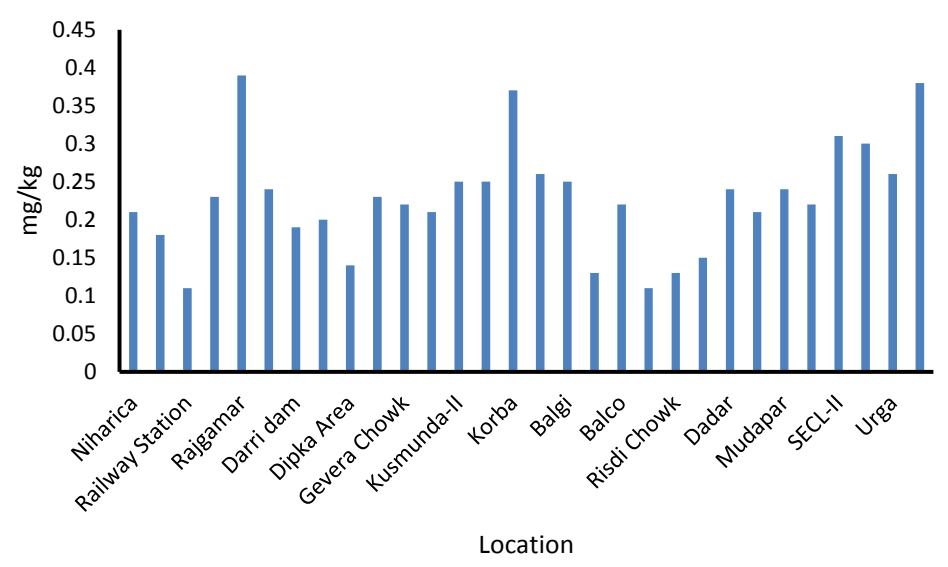

(a)

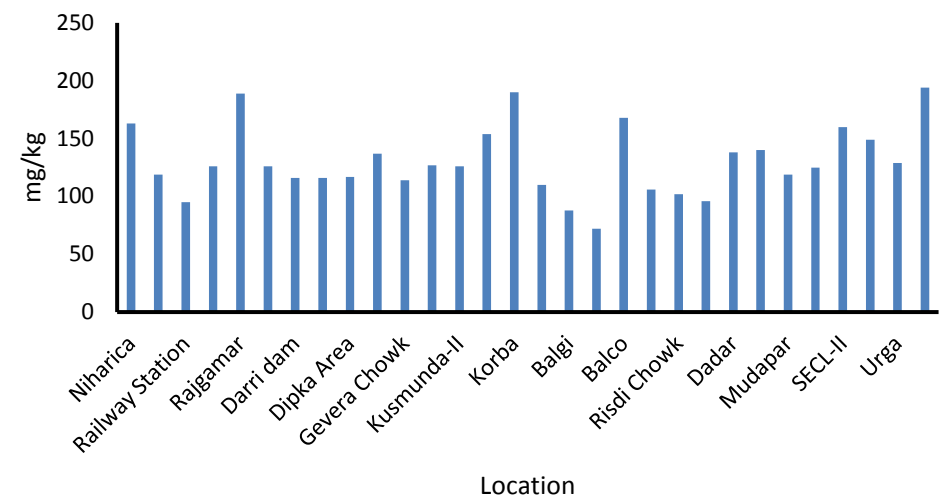

(b)

Figure 3. Spatial distribution of $\mathrm{Hg}(\mathrm{a})$ and $\mathrm{Pb}(\mathrm{b})$ in soil.

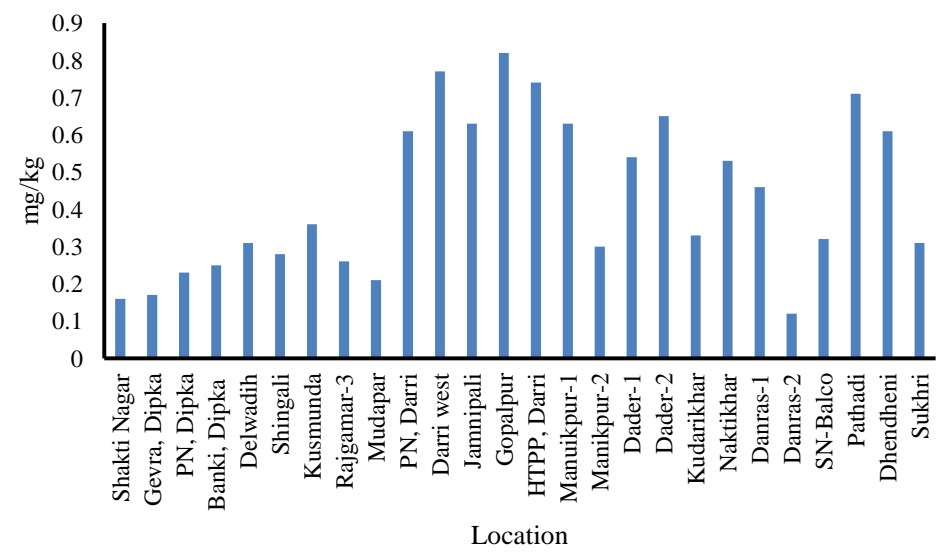

(a) 


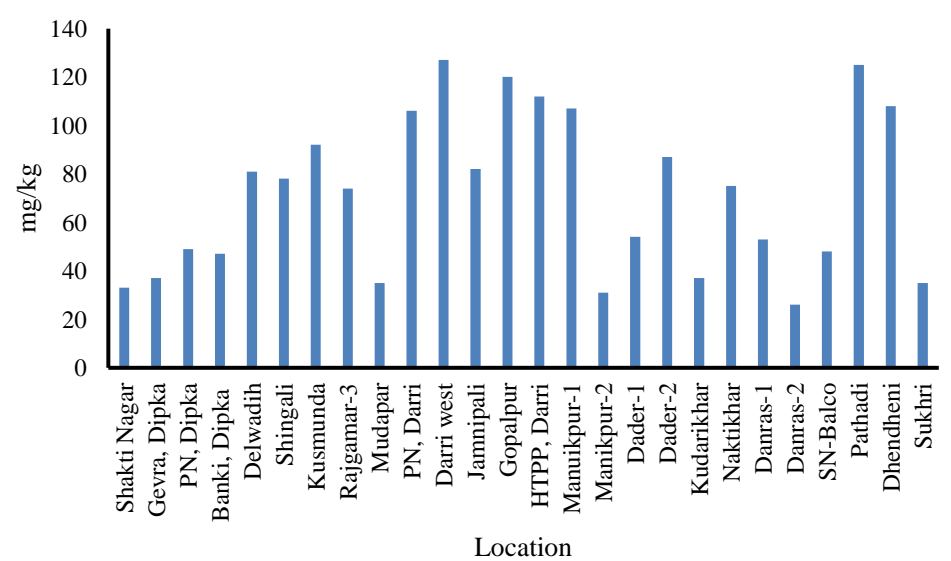

(b)

Figure 4. Spatial distribution of $\mathrm{Hg}(\mathrm{a})$ and $\mathrm{Pb}(\mathrm{b})$ in sediment.

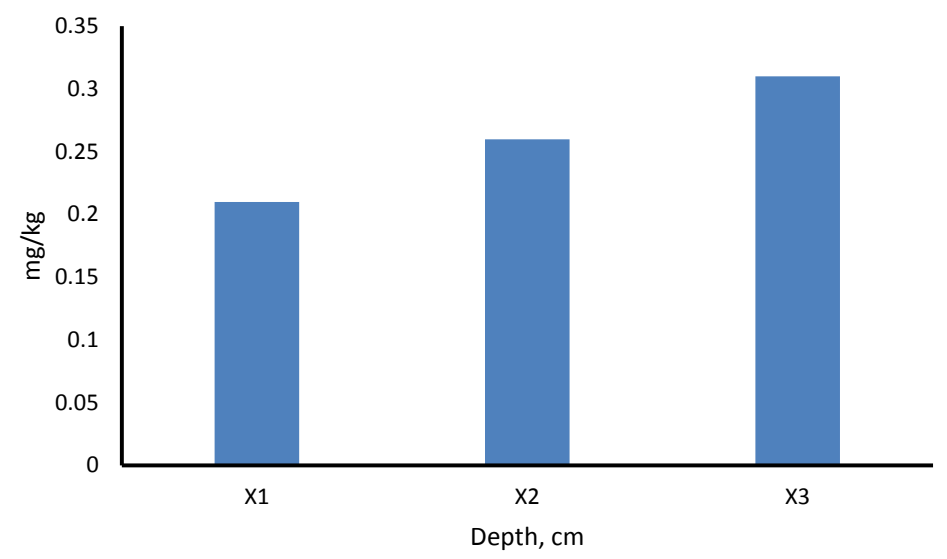

(a)

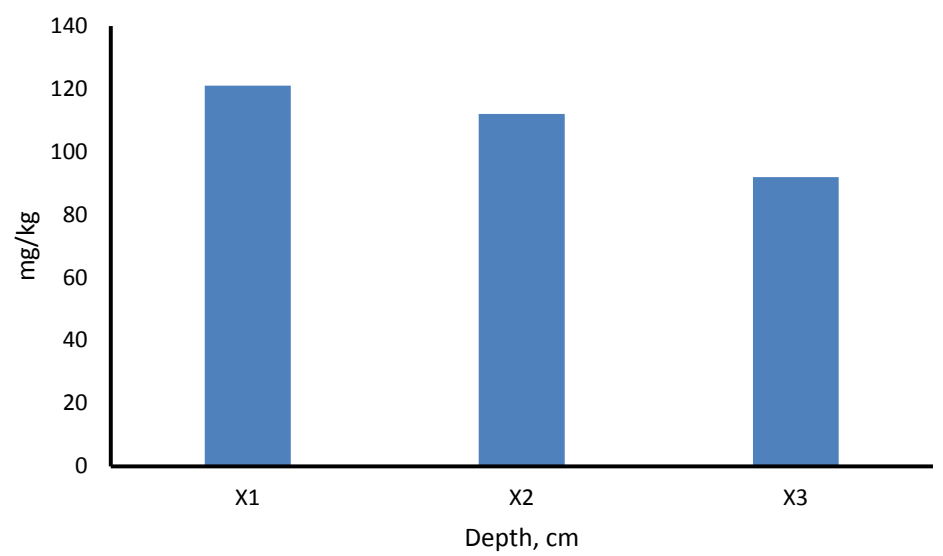

(b)

Figure 5. Depth profile studies of $\mathrm{Hg}$ (a) and $\mathrm{Pb}(\mathrm{b})$ in soil, $\mathrm{X} 1=0-10$ $\mathrm{cm}, \mathrm{X} 2=10-20 \mathrm{~cm}, \mathrm{X} 3=20-30 \mathrm{~cm}$.

\subsection{Enrichment of Metals}

The background concentration of $\mathrm{Hg}$ and $\mathrm{Pb}$ in the soil reported is 0.05 and $17 \mathrm{mg} / \mathrm{kg}$, respectively [50]. The $\mathrm{Hg}$ and $\mathrm{Pb}$ in the $\mathrm{PM}_{10}$ was found to be extremely $(1049 \pm 261)$ and significantly $(18 \pm 8)$ enriched, respectively. However, they were found to be moderately enriched in the soil and sediment of the studied area, Figure 6. 


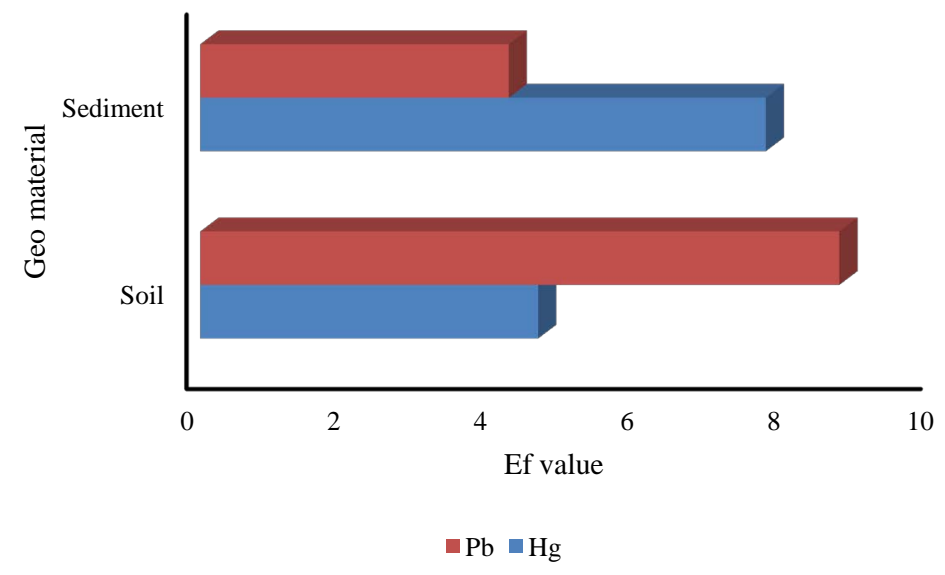

Figure 6. Enrichment of $\mathrm{Pb}$ and $\mathrm{Hg}$ in soil and sediment.

\subsection{Sources of Metals}

The PM and EC in the air are mainly generated during the burning processes. A good correlation $(r=0.98)$ of the EC with the PM was achieved, showing origin from the burning processes. Similarly, the EC with $\mathrm{Pb}$ and $\mathrm{Hg}$ contents in the air, soil and sediment was found to be fairly correlated $(r=0.63-0.81)$, indicating origin mainly from the coal burning processes.

\section{Conclusion}

The enrichment of $\mathrm{Hg}$ and $\mathrm{Pb}$ in the environment depends strongly on the particle size of the sorbent, and their remarkable higher concentrations are observed in the ambient $\mathrm{PM}_{10}$. Mercury was enriched $>100$-folds higher in the ambient $\mathrm{PM}_{10}$ with respect to the soil and sediment media. The increased vertical mobility of $\mathrm{Hg}$ via the soil was marked unlikely to $\mathrm{Pb}$. The coal burning and mining are expected to be the major sources for contaminations of the metals in the environment.

\section{Acknowledgements}

We are thankful to our University (PRSU) for granting scholarship to one of the authors: RS.

\section{References}

[1] Bernhoft, R.A. (2012) Mercury Toxicity and Treatment: A Review of the Literature. Journal of Environmental and Public Health, 2012, 1-10. http://dx.doi.org/10.1155/2012/460508

[2] Murata, K., Iwata, T., Dakeishi, M. and Karita, K. (2009) Lead Toxicity: Does the Critical Level of Lead Resulting in Adverse Effects Differ between Adults and Children? Journal of Occupational Health, 51, 1-12. http://dx.doi.org/10.1539/joh.K8003

[3] Yudovich, Y.E. and Ketris, M.P. (2005) Mercury in Coal: A Review Part 2. Coal Use and Environmental Problems. International Journal of Coal Geology, 62, 135-165. http://dx.doi.org/10.1016/j.coal.2004.11.003

[4] Patra, K.C., Rautray, T.R., Tripathy, B.B. and Nayak, P. (2012) Elemental Analysis of Coal and Coal ASH by PIXE Technique. Applied Radiation and Isotopes, 70, 612-616. http://dx.doi.org/10.1016/j.apradiso.2011.12.013

[5] Bhangare, R.C., Ajmal, P.Y., Sahu, S.K., Pandit, G.G. and Puranik, V.D. (2011) Distribution of Trace Elements in Coal and Combustion Residues from Five Thermal Power Plants in India. International Journal of Coal Geology, 86, 349-356. http://dx.doi.org/10.1016/j.coal.2011.03.008

[6] Soni, D.K., Chakrabarti, S.P. and Aggarwal, A.L. (2000) Heavy Metal Emission from Thermal Power Plants and its Implication on Vegetative Environment-A Case Study. Environmental Stress: Indication, Mitigation and Eco-Conservation, 153-164. http://dx.doi.org/10.1007/978-94-015-9532-2_14

[7] Labus, K. (1995) Heavy-Metal Emissions from Coal Combustion in Southwestern Poland. Energy, 20, 1115-1119. http://dx.doi.org/10.1016/0360-5442(95)00062-L

[8] Meij, R. and Winkel, H. (2007) The Emissions of Heavy Metals and Persistent Organic Pollutants from Modern Coal- 
Fired Power Stations. Atmospheric Environment, 41, 9262-9272. http://dx.doi.org/10.1016/j.atmosenv.2007.04.042

[9] Lu, J.Y. and Schroeder, W.H. (1999) Sampling and Determination of Particulate Mercury in Ambient Air: A Review. Water Air and Soil Pollution, 112, 279-295.

[10] Keegan, T.J., Farago, M.E., Thornton, I., Hong, B., Colvile, R.N., Pesch, B., Jakubis, P. and Nieuwenhuijsen, M.J. (2006) Dispersion of As and Selected Heavy Metals around a Coal-Burning Power Station in Central Slovakia. Science of the Total Environment, 358, 61-71.

[11] Schleicher, N.J., Schäfer, J., Blanc, G., Chen, Y., Chai, F., Cen, K. and Norra, S. (2015) Atmospheric Particulate Mercury in the Megacity Beijing: Spatio-Temporal Variations and Source Apportionment. Atmospheric Environment, 109, 251-261. http://dx.doi.org/10.1016/j.atmosenv.2015.03.018

[12] Sheu, G.R., Lin, N.H., Lee, C.T., Wang, J.L., Chuang, M.T., Wang, S.H., Chi, K.H. and Ou-Yang, C.F. (2013) Distribution of Atmospheric Mercury in Northern Southeast Asia and South China Sea during Dongsha Experiment. Atmospheric Environment, 78, 174-183. http://dx.doi.org/10.1016/j.atmosenv.2012.07.002

[13] Cairns, E., Tharumakulasingam, K., Athar, M., Yousaf, M., Cheng, I., Huang, Y., Lu, J. and Yap, D. (2011) Source, Concentration, and Distribution of Elemental Mercury in the Atmosphere in Toronto, Canada. Evironmental Pollution, 159, 2003-2008. http://dx.doi.org/10.1016/j.envpol.2010.12.006

[14] Ruelas-Inzunza, J., Delgado-Alvarez, C., Frías-Espericueta, M. and Páez-Osuna, F. (2013) Mercury in the Atmospheric and Coastal Environments of Mexico. Reviews of Environmental Contamination and Toxicology, 226, 65-99. http://dx.doi.org/10.1007/978-1-4614-6898-1_3

[15] Kim, P.R., Han, Y.J., Holsen, T.M. and Yi, S.M. (2012) Atmospheric Particulate Mercury: Concentrations and Size Distributions. Atmospheric Environment, 61, 94-102. http://dx.doi.org/10.1016/j.atmosenv.2012.07.014

[16] Rodriguez Martin, J.A., Nanos, N., Grigoratos, T., Carbonell, G. and Samara, C. (2014) Local Deposition of Mercury in Topsoils around Coal-Fired Power Plants: Is It Always True? Environmental Science and Pollution Research International, 21, 10205-10214. http://dx.doi.org/10.1007/s11356-014-2873-0

[17] Liang, Y., Yuan, D., Lu, M., Gong, Z., Liu, X. and Zhang, Z. (2009) Distribution Characteristics of Total Mercury and Methylmercury in the Topsoil and Dust of Xiamen, China. Journal of Environmental Sciences, 21, 1400-1408. http://dx.doi.org/10.1016/S1001-0742(08)62432-8

[18] Solgi, E., Esmaili-Sari, A. and Riyahi-Bakhtiari, A. (2014) Spatial Distribution of Mercury in the Surface Soils of the Urban Areas, Arak, Iran. Bulletin of Environmental Contamination and Toxicology, 93, 710-715. http://dx.doi.org/10.1007/s00128-014-1408-1

[19] Gray, J.E., Theodorakos, P.M., Fey, D.L. and Krabbenhoft, D.P. (2015) Mercury Concentrations and Distribution in Soil, Water, Mine Waste Leachates, and Air in and around Mercury Mines in the Big Bend Region, Texas, USA. Environmental Geochemistry and Health, 37, 35-48. http://dx.doi.org/10.1007/s10653-014-9628-1

[20] Dąbkowska-Naskręt, H. and Różański, S.Z. (2007) Mercury Content in Garden Soils of Urban Agglomeration. Global NEST Journal, 9, 237-241.

[21] Shi, J.B., Ip, C.C.M., Tang, C.W.Y., Zhang, G., Wu, R.S.S. and Li, X.D. (2007) Spatial and Temporal Variations of Mercury in Sediments from Victoria Harbour, Hong Kong. Marine Pollution Bulletin, 54, 480-485. http://dx.doi.org/10.1016/j.marpolbul.2006.11.016

[22] Ram, A., Rokade, M.A. and Zingde, M.D. (2009) Mercury Enrichment in Sediments of Amba Estuary. Indian Journal of Marine Sciences, 38, 89-96.

[23] Boszke, L. and Kowalski, A. (2006) Spatial Distribution of Mercury in Bottom Sediments and Soils from Poznań, Poland. Polish Journal of Environmental Studies, 15, 211-218.

[24] Laperche, V., Hellal, J., Maury-Brachet, R., Joseph, B., Laporte, P., Breeze, D. and Blanchard, F. (2014) Regional Distribution of Mercury in Sediments of the Main Rivers of French Guiana (Amazonian Basin). Springer Plus, 3, 322. http://dx.doi.org/10.1186/2193-1801-3-322

[25] Shreadah, M.A. Ghani, S.A.A., Taha, A.A.E.S., Ahmed, M.M.A.E. and Hawash, H.B.I. (2012) Mercury and Methyl Mercury in Sediments of Northern Lakes-Egypt. Journal of Environmental Protection, 3, 254-261. http://dx.doi.org/10.4236/jep.2012.33032

[26] Shao, D., Liang, P., Kang, Y., Wang, H., Cheng, Z., Wu, S., Shi, J., Lo, S.C., Wang, W. and Wong, M.H. (2011) Mercury Species of Sediment and Fish in Freshwater Fish Ponds around the Pearl River Delta, PR China: Human Health Risk Assessment. Chemosphere, 83, 443-448. http://dx.doi.org/10.1016/j.chemosphere.2010.12.080

[27] Souza, V.A. and Wasserman, J.C. (2014) Mercury Distribution in Sediments of a Shallow Tropical Reservoir in Brazil. Geochimica Brasiliensis, 28, 149-160. http://dx.doi.org/10.5327/Z0102-9800201400020004

[28] Li, H.B., Yu, S., Li, G.L., Deng, H., Xu, B., Ding, J., Gao, J.B., Hong, Y.W. and Wong, M.H. (2013) Spatial Distribution and Historical Records of Mercury Sedimentation in Urban Lakes under Urbanization Impacts. Science of the To- 
tal Environment, 445-446, 117-125. http://dx.doi.org/10.1016/j.scitotenv.2012.12.041

[29] Chandra, S., Kulshrestha, M.J. and Singh, R. (2014) Temporal Variation and Concentration Weighted Trajectory Analysis of Lead in $\mathrm{PM}_{10}$ Aerosols at a Site in Central Delhi, India. International Journal of Atmospheric Sciences, 2014, Article ID: 323040.

[30] Chaudhari, P.R., Gupta, R., Gajghate, D.G. and Wate, S.R. (2012) Heavy Metal Pollution of Ambient Air in Nagpur City. Environmental Monitoring and Assessment, 184, 2487-2496. http://dx.doi.org/10.1007/s10661-011-2133-4

[31] Li, X., Zhang, Y., Tan, M., Liu, J., Bao, L., Zhang, G., Li, Y. and Iida, A. (2009) Atmospheric Lead Pollution in Fine Particulate Matter in Shanghai, China. Journal of Environmental Sciences, 21, 1118-1124. http://dx.doi.org/10.1016/S1001-0742(08)62390-6

[32] Melaku, S., Morris, V., Raghavan, D. and Hosten, C. (2008) Seasonal Variation of Heavy Metals in Ambient Air and Precipitation at a Single Site in Washington DC. Environmental Pollution, 155, 88-98. http://dx.doi.org/10.1016/j.envpol.2007.10.038

[33] Chiemeka, I.U. (2010) Air Aerosol Metal Constituent and Concentration at Okigwe, Nigeria. International Journal of Physical Sciences, 5, 283-286.

[34] Li, H.B., Yu, S., Li, G.L., Deng, H. and Luo, X.S. (2011) Contamination and Source Differentiation of Pb in Park Soils along an Urban-Rural Gradient in Shanghai. Environmental Pollution, 159, 3536-3544. http://dx.doi.org/10.1016/j.envpol.2011.08.013

[35] Ona, L.F., Alberto, A.M.P., Prudente, J.A. and Sigua, G.C. (2006) Levels of Lead in Urban Soils from Selected Cities in a Central Region of the Philippines. Environmental Science and Pollution Research, 13, 177-183. http://dx.doi.org/10.1065/espr2005.08.275

[36] Nabulo, G., Oryem-Origa, H. and Diamond, M. (2006) Assessment of Lead, Cadmium, and Zinc Contamination of Roadside Soils, Surface Films, and Vegetables in Kampala City, Uganda. Environmental Research, 101, 42-52. http://dx.doi.org/10.1016/j.envres.2005.12.016

[37] Brown, R.W., Gonzales, C., Hooper, M.J., Bayat, A.C., Fornerette, A.M., McBride, T.J., Longoria, T. and Mielke, H.W. (2008) Soil Lead (Pb) in Residential Transects through Lubbock, Texas: A Preliminary Assessment. Environmental Geochemistry and Health, 30, 541-547. http://dx.doi.org/10.1007/s10653-008-9180-y

[38] Reeder, P. and Shapiro, L. (2003) Lead Contamination of Soils in Belize City, Belize, Central America. Journal of Environmental Science and Health Part A, 38, 2785-2805. http://dx.doi.org/10.1081/ESE-120025831

[39] Duzgoren-Aydin, N.S. (2007) Sources and Characteristics of Lead Pollution in the Urban Environment of Guangzhou. Science of the Total Environment, 385, 182-195. http://dx.doi.org/10.1016/j.scitotenv.2007.06.047

[40] Imperato, M., Adamo, P., Naimo, D., Arienzo, M., Stanzione, D. and Violante, P. (2003) Spatial Distribution of Heavy Metals in Urban Soils of Naples City (Italy). Environmental Pollution, 124, 247-256. http://dx.doi.org/10.1016/S0269-7491(02)00478-5

[41] Li, H.B., Yu, S., Li, G.L. and Deng, H. (2012) Lead Contamination and Source in Shanghai in the Past Century Using Dated Sediment Cores from Urban Park Lakes. Chemosphere, 88, 1161-1169. http://dx.doi.org/10.1016/j.chemosphere.2012.03.061

[42] Stamatis, N., Kamidis, N. and Sylaios, G. (2006) Sediment and Suspended Matter Lead Contamination in the Gulf of Kavala, Greece. Environmental Monitoring and Assessment, 115, 433-449. http://dx.doi.org/10.1007/s10661-006-7238-9

[43] Gale, N.L., Adams, C.D., Wixson, B.G., Loftin, K.A. and Huang, Y.W. (2004) Lead, Zinc, Copper, and Cadmium in Fish and Sediments from the Big River and Flat River Creek of Missouri’s Old Lead Belt. Environmental Geochemistry and Health, 26, 37-49. http://dx.doi.org/10.1023/B:EGAH.0000020935.89794.57

[44] Christophoridis, A., Stamatis, N. and Orfanidis, S. (2007) Sediment Heavy Metals of a Mediterranean Coastal Lagoon: Agiasma, Nestos Delta, Eastern Macedonia (Greece). Transitional Waters Bulletin, 4, 33-43.

[45] Abdel Ghani, S., El Zokm, G., Shobier, A., Othman, T. and Shreadah, M. (2013) Metal Pollution in Surface Sediments of Abu-Qir Bay and Eastern Harbour of Alexandria, Egypt. The Egyptian Journal of Aquatic Research, 39, 1-12. http://dx.doi.org/10.1016/j.ejar.2013.03.001

[46] Tan, K.H. (2005) Soil Sampling, Preparation and Analysis. 2nd Edition, CRC Press, Boca Raton.

[47] IAEA (2003) Collection and Preparation of Bottom Sediment Samples for Analysis of Radionuclides and Trace Elements. http://www-pub.iaea.org/MTCD/Publications/PDF/te_1360_web.pdf

[48] Walkley, A. and Black, I.A. (1934) An Examination of the Degtjareff Method for Determining Soil Organic Matter, and a Proposed Modification of the Chromic Acid Titration Method. Soil Science, 37, 29-38. http://dx.doi.org/10.1097/00010694-193401000-00003

[49] EPA (1996) Air Quality Criteria for Particulate Matter, Vol. III, EPA/600/P-95/001cF. 
http://cfpub.epa.gov/ncea/cfm/recordisplay.cfm?deid=2832

[50] Rudnick, R.L. and Gao, S. (2003) Composition of the Continental Crust. In: Rudnick, R.L., Holland, H.D. and Turekian, K.K., Eds., Treatise on Geochemistry, Vol. 3, Elsevier-Pergamon, Oxford, 1-64.

http://dx.doi.org/10.1016/b0-08-043751-6/03016-4 